\title{
The Relationship between Sources of Moral Authority, Political Attitude and Authoritarianism
}

\author{
Ali Teymoori \\ School of Psychology and Human Development, Faculty of Social Sciences and Humanities \\ Universiti Kebangsaan Malaysia, 43600 UKM Bangi, Selangor, Malaysia \\ Tel: 60-17-701-1153 E-mail: ali_ty65@yahoo.com \\ Wan Shahrazad W. S. \\ School of Psychology and Human Development, Faculty of Social Sciences and Humanities \\ Universiti Kebangsaan Malaysia, 43600 UKM Bangi, Selangor, Malaysia \\ Tel: 60-3-8921-4190 E-mail: shara@ukm.my \\ Arash Heydari \\ Faculty of Social Sciences and Economics, Shahid Chamran University of Ahvaz, Iran \\ Tel: 98-91-6959-1697_E-mail: arash.heidary@yahoo.com
}

$\begin{array}{ll}\text { Received: November 13, } 2011 & \text { Accepted: December 22, } 2011 \quad \text { Published: April 1, } 2012 \\ \text { doi:10.5539/ass.v8n4p50 } & \text { URL: http://dx.doi.org/10.5539/ass.v8n4p50 }\end{array}$

\begin{abstract}
Individuals with different political attitudes attribute their political tendencies to different sources of moral authority. This study aimed to investigate the relationship between moral authority sources, political attitude and authoritarianism. A total of 128 subjects from two universities participated in this study by completing the Moral Authority Test-Revised (MAS-R) and the Authoritarianism Scale. Respondents were also asked regarding their political tendencies. Findings showed no significant difference of political attitudes in attribution to different sources of moral authority and authoritarianism. There was however a significant relation of authoritarianism with external source of moral authority, but not with principle and self interest sources. This implies that authoritarians relied on external source of authority figures in moral judgment rather than one's own interest or principle issues. The findings were discussed in terms of the characteristics of the sample and sociopolitical sphere of Iran.
\end{abstract}

Keywords: Moral authority sources, Political attitude, Authoritarianism, External source, Principle source

\section{Introduction}

The political approaches of individuals are varied in a wide range of issues, but usually they are brought to a contradictory continuum which is usually labeled differently across nations. The continuum of left and right in some of the western countries or conservative and liberalism in United States is an example of the extreme sides of the continuum. The differences of these two extreme political ideologies have always been the focus of psychosocial research specifically from their personality and morality viewpoints. However, results of previous studies have not always been consistent. For instance, the relation of political tendencies with morality has been contradictory and it is not clear whether individuals with different political ideologies are different from each other in their sources of moral authority.

From the moral reasoning point of view, conservative political attitude (right-wing orientation) is found to be associated with lower level of moral reasoning. In contrast, liberals (left-wing orientation) have shown higher maturity in their morality (Candee and Kohlberg, 1987; Emler et al., 1983; Haan et al., 1968; Kohlberg and Candee, 1984; Raaijmakers and Hoof, 2006). Conversely, from another point of view, it has been found that conservatives have a wide range of moral spectrum while liberals have a limited number of moral foundations. 
Graham et al. (2009) said that liberals mostly endure the harm/care and fairness/reciprocity foundations of morality while conservatives use five foundations of morality which are harm/care, fairness/reciprocity, in-group/loyalty, authority/respect, and purity/sanctity. Skitka and Bauman (2008), on the other hand, demonstrated that the conservatives and liberals are not different in their political engagement, they stated that "the effects of moral conviction on political engagement are equally strong for those on the political right and left" (p. 50).

In another study, Leeuwen and Park (2009) found that the liberals put the priority of their judgment to the "individualizing foundations (harm/care and fairness/reciprocity)". Conversely the conservatives' judgments are based on respect to the authority and loyalty principles. Based on the evidences of the political ideology and morality relations, Emler et al. (1983) asserted that strong association of political tendency with morality refers to their mutual origin and overlapping domain.

In Raaijmakers and Hoof's (2006) study, a direct association between political ideology and moral reasoning with human rights was found, and results showed that "moral reasoning affects general moral thought (assessed by the human rights questionnaire), just as political psychology does" (p. 634). In fact, the research on Free Speech Movement (FSM) can be considered as a turning point and the beginning of debate on the differences of individuals with different political ideologies in their morality. Free speech movement has mostly been cited as the relation of moral judgment with moral action in which students who have higher stage of moral reasoning are more likely to engage in moral action (Candee and Kohlberg, 1987; Kohlberg and Candee, 1984).

Haan et al. (1968) studied sociopolitical behavior, family background, and personality of the students who were arrested at the University of California (because of their demonstrations as FSM supporters) and other groups of students. They found that the students who were at the postconventional level of moral reasoning were more supportive of free speech movement, less religious, politically liberal, and personally autonomous; they have grown up in more educated liberal families compared with the conservative subjects. Also, students with high level of morality have more concern with political-societal activities. This is consistent with findings by Thomas et al. (1999) who found that individuals with conservative political tendency are more in conventional stage of moral reasoning and liberals are more in post conventional stage of moral judgment.

Iran is a very special case from political point of view. With a long history of civilization, it has a royal government for nearly 2500 years. The governments have always considered themselves as owners of the country and the people. The government has the right to decide about every affair and people should obey. Manifest characteristic of such government was that their legitimacy was basically not from the people. Downfall of the dictatorship government has not led to elimination of dictatorship system but was replaced with another dictatorship. Change of the government from one to another has always come along with sedition, riot, revolutions, and civil or external wars which led to anarchy, chaos, despoliation and destruction. Thus, autocracy has a deep root in the social structure of Iran. Unfortunately, intellectuals and political thinkers of Iran have always sought the root of authoritarianism in political elites and they viewed the dictatorship as a political phenomenon. It should be noted, however, authoritarianism is also a social problem, besides political and psychological aspects, which caused the continuity of authoritarianism and totalitarianism. This explanation makes authoritarianism a serious problem with which its characteristics and its effects with other factors within Iranian community should be scrutinized.

In particular, it has been frequently concluded that morality is associated with authoritarian personality. For instance, following powerful individuals and fulfilling their expectations is one of the traits of authoritarians. From political viewpoint, the authoritarians favor the right wing and they are conservative in their political spectrum than other parties (Altemeyer, 1998; Jost et al., 2003; Tarr and Lorr, 1991; Todosijevic and Enyedi, 2008). Morality of an authoritarian person is indeed oriented to directions in which obedience to authority figures and keeping the requirements of powerful individuals have priority on individuals' own will (Van IJzendoorn, 1989; Cockroft, 1995). Van IJzendoorn (1989) stated that "authoritarian personality is supposed to result from problematic moral development" (p. 38). However, in another study, he (1997) did not find significant association between authoritarianism and morality. Napier and Jost (2008) considered four characteristics for authoritarian people based on the literature which are conventionalism, moral absolutism, obedience to authority, and cynicism. However, they found that authoritarianism was strongly associated with obedience to authority and cynicism in lower socioeconomic status but not with morality of lower social class. It seems that authoritarian people rely on authority figures while making a decision and judging a moral issue. They would not be capable of ascribing to principle source of moral reasoning as obeying authority and following expectations of others can fit well with heterogenous morality (Van IJzendoorn, 1997). 
This study was undertaken to find out what are the differences of individuals with different political attitudes in ascribed sources of moral authority. Besides that, this study was conducted in Iran in which this issue has been given little emphasis. The relation of authoritarianism with conservative political tendency and morality has been addressed and studied previously but in the Western context. More precisely, there is little scientific information about both political issues and authoritarianism in Iran. Three main objectives of this study are: (1) to examine the moral authority sources, authoritarianism and political tendencies of respondents, (2) to examine the relationship between authoritarianism and moral authority sources, and (3) to examine the differences of moral authority sources among the conservatives and reformists.

\section{Method}

\subsection{Participants}

A total of 128 undergraduate students from two different cities of Semirom and Abade in Iran participated as respondents in this study. Age of subjects ranged from 17 to 24 years old with the mean age of 20.41 and standard deviation of 1.51. Fifty eight of the subjects were male and 68 were female and two of them did not mention their gender. The ethnic distribution of the subjects was 90 Fars, 20 Turk, 5 Lur, 2 Kurd, 9 other ethnics, and two did not mention their ethnicity.

\subsection{Instruments}

The research instruments consisted of two standardized instruments and one part that requested respondents' background information. The instruments were:

i. The Moral Authority Scale Revised (MAS-R)

Moral Authority Scale Revised (MAS-R) was developed by White $(1996,1997)$ based on the psychodynamic approach of Henry (1983). MAS-R assesses individual differences in attribution to sources of moral authority. It does not assess the different levels or adequacy of individuals' morality, rather it assesses the degree of attribution to different sources of influence during moral decision making. In other words, MAS-R is willing to capture the information about "who or what" and to what extent these sources have an influence on moral judgment of individuals.

White offered six socio-moral questions that respondents should answer in either "yes/ no/ can't decide" and then it is followed by open-ended questions which asked why the respondent believes in that way. The subjects are asked to rate the influence of each source on their judgment about the moral question in a 10-point Likert-format scale from "0-No Influence" to "10-A Powerful Influence". Five sources of moral authority are listed by White in Moral Authority Scale as follows: family, media and teacher or educators, society welfare, equality, and self interest sources. The Moral Authority Scale-Revised has showed good psychometric properties. MAS-R has test-retest reliabilities for the subscales ranging from .75 to .93 (self interest $=.88$, family $=.93$, educators $=.93$, society's welfare $=.75$, equality $=.82$ ) over a period of four weeks and very high internal consistencies as well ranging from .95 to .98 (self interest $=.96$, family $=.98$, educators $=.97$, society's welfare $=.95$, equality $=.95)$ (White, 1997). MAS-R showed to have convergent and discriminant validity as well. The convergent validity was between the stages of Defining Issues Test (DIT) and relevant sources of moral authority such as positive correlation of society welfare and equality sources with stage 5 of DIT, and self interest source with stage 2 of DIT. In addition, the discriminant validity has been found between the MAS-R and Vision of Morality Scale (White, 1997). The Moral Authority Scale was translated and validated in Persian by Teymoori et al. (in press). The translation was done by back translation method.

\section{ii. The Authoritarianism Scale}

After reviewing famous scales in this field, Heydari et al. (2012) chose items from authoritarian scales of Adorno et al. (1950) and Altemeyer (1998) that were in accord with socio-cultural and political spheres of Iran. Because of specific socio-cultural and political context of Iran, they left some aspects of scales by obligation such as the items of $\mathrm{F}$ scale measuring politically and culturally sensitive issues which were thought to cause bias in participants and decrease the reliability of the responses. Heydari et al. (2012) finalized 12 items for the authoritarianism scale. An example of the item is "People should obey their superiors whether or not they think they are right", "Obedience and respect for authority are the most important virtues children should learn". Answers of items are on a 5-point Likert scale from 5 (strongly agree) to 1 (strongly disagree). The scale has a reliability coefficient of 0.88 .

iii. Political attitude and demographic information 
The demographic questionnaire consisted of questions of age and gender. Respondents were required to show their political tendency as well. Based on the politically active parties in Iran, participants were asked to indicate their political tendencies according to the following scale: very reformist, neither reformist nor conservative, somewhat conservative, and very conservative. Reformist beliefs are similar to the liberals and the conservative party is similar to the right wing political attitude.

\section{Results and Discussion}

The first objective of this study was to examine the moral authority sources, authoritarianism and political tendencies of respondents. Results of descriptive statistics in Table 1 show the mean and standard deviation of moral authority and authoritarianism. Table 2 presents the distribution of the individuals at each of the political attitude. (see Table 1 and Table 2).

Respondents obtained very high authoritarianism scores with the mean of authoritarianism tendency was more than half of the possible maximum score of the scale implying seriousness of this problem. Accordingly, Ji and Suh (2008), by comparing Korean students with Americans, stated that Asian countries have more authoritarian submission and aggression. In fact, they found that Korean students were more compliant to authority, more aggressive to out-group and less conservative in their social beliefs in comparison with American students. Results showed that a total of $30.5 \%$ respondents categorized themselves as very reformist and another $37.5 \%$ categorized themselves as neither reformist nor conservative. Results also showed the low number of participants in both "somewhat conservative" and "very conservative". This may be explained by the socio-cultural factors which may explain the negative bias of the participants to the direct political questions due to the specific political sphere.

Dean (2004) believed that the authoritarian characteristics were still evident in some individuals who have desperate need to rely on authority figures, supportive of strong leader, and have right wing political tendency. She stated that the authoritarian tendency would increase if the authoritarian individuals' security was threatened. This was clearly explained by Oesterreich (2005) since he considered authoritarian reaction as a "flight into security" because it occurred in a form of individuals' basic response to anxiety, stressful situation, uncertainty, and insecurity (Oesterreich, 2005, p. 282). This proposition was confirmed in Iranian society as well as in Heydari et al.'s (2012) study which found significant relation of anomic feeling with authoritarianism and also the authoritarian was predicted significantly by anomie of the individuals.

The second objective of the study examined the relationship between moral authority sources and authoritarianism. As shown in Table 3, authoritarianism has significant relation with external source of moral judgment $(\mathrm{r}=.18, \mathrm{p}<.05)$. The more authoritarian individuals were, the more attribution was given to external sources of moral judgment namely family, peer and educators or media sources. Authoritarianism, however, was not related to self interest $(r=.07, p>.05)$ and principle source $(r=.07, p>.05)$ of moral authority. (refer Table $3)$.

The significant relation of authoritarianism, as a sound characteristic of the right wing, with external source of moral authority is consistent with the literature. This finding is in alignment with authoritarianism definition that is following the authority expectations and authority figures. Accordingly, the finding is consistent with Van IJzendoorn's $(1989,1997)$ and Cockroft's (1995) propositions about authoritarian characteristics while it is inconsistent with Napier and Jost's (2008) in which they found no significant relation of authoritarianism with morality in lower socioeconomic status. However, they did consider the moral absolutism as one of the authoritarian characteristics. Van IJzendoorn (1997) stated that the authoritarian's morality was like heterogenous morality, and authoritarianism relation with external source of moral judgment confirmed Van IJzendoorn's proposition. It is noteworthy to mention that the authoritarianism was not related to the self interest and principle source of moral judgment. The lack of authoritarians' relation with self interest and principle source is another indicator of their obedience to authority figure and priority of others' expectation to ones' own.

The third objective was to examine the differences of moral authority sources and authoritarianism according to political attitudes. ANOVA analysis was conducted to see whether different political attitudes have significant differences in their attribution to moral sources and authoritarianism. There were no significant differences among the different political attitude in attribution to external, $\mathrm{F}(3,109)=.45, \mathrm{p}>.05$, principle source, $\mathrm{F}(3,110)$ $=.28, \mathrm{p}>.05$, and self interest source, $\mathrm{F}(3,110)=.35, \mathrm{p}>.05$ and even in authoritarian individuals, $\mathrm{F}(3,105)=$ $2.06, p>.05$. The results are shown in Table 4. (refer Table 4).

The hypothesis of the research that examined the differences of conservative and reformists in ascribed sources of moral authority and authoritarianism was not confirmed and individuals with different political ideology or without any political affiliation did not show any significant differences in their moral authority and 
authoritarianism. This result is contradictory with the results of previous studies (Raaijmakers and Hoof, 2006; Leeuwen and Park, 2009; Emler et al., 1983; Graham et al., 2009; Haan et al., 1968; Kohlberg and Candee, 1984; Candee and Kohlberg, 1987). However during the validation process of the MAS-R, White (1997) found that different political affiliations varied in attribution to society welfare, equality and educators sources of moral authority in which those subjects in either left wing or right wing were associated with more attribution to society welfare source than those of without any political tendency. In addition, she found that left wing was related with more attribution to equality source than the group of no political attitude.

One possible explanation for inconsistency of the findings in the current study with findings of White (1997) might be due to the differences in sources of attribution. In other words, there could be other sources that conservatives and reformists were different in like religion source, culture and traditions, institutional sources, individuality or collectivism, or authority. This implies the cultural differences among participants of the two studies which refer to differences of the Eastern and Western culture. Whether the conservatives and reformists are different in attribution to sources that were just mentioned needs to be examined in future studies.

The lack of authoritarianism relation with political attitudes might be interpreted in the context that criticizing and opposing the current situation cannot be due to democratic nature of individuals. Reformist party in Iran cannot be called as a pure democratic party, rather it is a movement against the current situation of the country which does not necessarily have democratic demands. Manifestation of reformism phenomenon in Iranian society had twisted with populism in 1376 (or 1997). Implicitly, it can be concluded that being reformist in Iranian community does not necessarily define a person as an anti-authoritarian. Interestingly, many of those who call themselves as reformist, in their familial and interpersonal relationship and social attitude, are completely authoritarian.

\section{Conclusion}

There are some limitations in this study. First, it was conducted in small cities and the universities which were not active in political issues. If the sample was taken from bigger universities especially the ones that are really active in political issues and also have politically active student communities, the results might differ dramatically since the differences of individuals with different political affiliations are more sound,

Finally, based on the socio-political sphere of Iran, it seems that besides asking the explicit question from participants, political attitude would be better captured by implicit way of asking the political tendency like the pessimistic view to authority, economic dimension of political ideology, freedom of expression and so forth. Authoritarianism as an alternative scale of right wing in the current study gave more consistent result with the literature due to its relation with external source of moral authority.

With a glimpse to the history of Iran, it can readily be seen that many of the movements which came to authority with slogan of criticism and reformation of the current situation fall into totalitarianism and authoritarianism (like constitutional revolution in 1279/1901). This is because the agents and proponents of these movements were authoritarian but apparently did not admit it. The differences in ideologies of conservatives and reformists are not sound. In other words, the advent of reformist party was just an objection to the current situation and it does not spring from a deep and distinct ideology. Therefore, non-significant relation of political attitude with authoritarianism in one hand and moral authority in the other seems to be due to the nature of political parties especially the reformist party.

\section{References}

Adorno, T. W., Frenkel-Brunswik, E., Levinson, D. J. \& Sanford, R. N. (1950). The Authoritarian Personality. NewYork: Harper \& Row.

Altemeyer, B. (1998). The Other Authoritarian Personality. In Zanna, M. (Ed.), Advances in Experimental Social Psychology, (Vol. 30, pp.47-92). San Diego: Academic Press.

Candee, D. \& Kohlberg, L. (1987). Moral Judgment and Moral Action: A Reanalysis of Haan, Smith, and Block's (1968) Free Speech Movement data. Journal of Personality and Social Psychology, 52(3), 554-564. http://dx.doi.org/10.1037/0022-3514.52.3.554

Cockroft, R. D. (1995). Personality and Authoritarian Moral System. Doctoral Dissertation: University of California, USA.

Dean, D. (2004). A Faustian Pact? Political Marketing and the Authoritarian Personality. Journal of Public Affairs, 4(3), 256-267. http://dx.doi.org/10.1002/pa.189 
Emler, N., Renwick, S. \& Malone, B. (1983). The Relationship between Moral Reasoning and Political Orientation. Journal of Personality and Social Psychology, 45(5), 1073-1080. http://dx.doi.org/10.1037/0022-3514.45.5.1073

Graham, J., Haidt, J. \& Nosek, B. A. (2009). Liberals and Conservative Rely on Different Sets of Moral Foundations. Journal of Personality and Social Psychology, 96(5), 1029-1046. http://dx.doi.org/10.1037/a0015141

Haan, N., Smith, M. B. \& Block, J. (1968). Moral Reasoning of Young Adults: Political-social Behavior, Family Background, and Personality Correlates. Journal of Personality and Social Psychology, 10(3), 183-201. http://dx.doi.org/10.1037/h0026566

Henry, M. R. (1983). The Psychodynamic Foundations of Morality. New York: Basel.

Heydari, A., Teymoori, A., Nassiri, H. \& Fardzadeh, E. H. (2012). Relationship between Socioeconomic Status, Anomie, and Authoritarianism. E-Bangi: Journal of Social Sciences and Humanities, 7(1), 176-188.

Ji, Chang-Ho C. \& Suh, Kyung H. (2008). Doctrinal Faith and Religious Orientations in Right-Wing Authoritarianism: A Pilot Study of American and Korean Protestant College Students. Journal of Psychology and Christianity, 27, 253-265.

Jost, J. T., Glaser, J., Kruglanski, A. W. \& Sulloway, F. J. (2003). Political Conservatism as Motivated Social Cognition. Psychological Bulletin, 129, 339-375. http://dx.doi.org/10.1037/0033-2909.129.3.339

Kohlberg, L. \& Candee, D. (1984). The Relationship of Moral Judgment to Moral Action. In Kurtines, W.M., and Gewirtz, J.L. Morality, Moral Behavior, and Moral Development. John Wiley \& Sons. Inc. Canada.

Leeuwen, F. V. \& Park, J. H. (2009). Perceptions of Social Dangers, Moral Foundations, and Political $\begin{array}{lllll}\text { Orientation. Personality and Individual } & \text { Differences, } & 47(3), & \text { 169-173. }\end{array}$ http://dx.doi.org/10.1016/j.paid.2009.02.017

Napier, J. L. \& Jost, J. T. (2008). The "Antidemocratic Personality" Revisited: A Cross-National Investigation of Working Class Authoritarianism. Journal of Social Issues, 64(3), 595-617. http://dx.doi.org/10.1111/j.1540-4560.2008.00579.x

Oesterreich, D. (2005). Flight into Security: A New Approach and Measure of the Authoritarian Personality. Political Psychology, 262, 275-297. http://dx.doi.org/10.1111/j.1467-9221.2005.00418.x

Raaijmakers, Q. A. W. \& Hoof, A. V. (2006). Does Moral Reasoning Represent Sociomoral Structure or Political Ideology? A Further Exploration of the Relations between Moral Reasoning, Political Attitudes, Consistency of Moral Thought, and the Evaluation of Human Rights in Dutch Young Adults. Social Behavior and Personality, 34(6), 617-638. http://dx.doi.org/10.2224/sbp.2006.34.6.617

Skitka, L. J. \& Bauman, C. W. (2008). Moral Conviction and Political Engagement. Political Psychology, 29(1), 29-54. http://dx.doi.org/10.1111/j.1467-9221.2007.00611.x

Tarr, H. \& Lorr, M. (1991). A Comparison of Right-wing Authoritarianism, Conformity, and Conservatism. Personality and Individual Differences, 12, 307-311. http://dx.doi.org/10.1016/0191-8869(91)90117-T

Teymoori, A., Wan Shahrazad, W. S., Heydari, A. \& Fardzadeh, H. E. (In Press). Validation of Moral Authority Scale-Revised in Persian: Criterion Validity and Internal Consistency. Procedia - Social and Behavioral Sciences.

Thomas, S. J., Narvaez, D., Rest, J. \& Derryberry, P. (1999). Does Moral Judgment Development Reduce to Political Attitudes or Verbal Ability? Evidence Using the Defining Issues Test. Educational Psychology Review, 11, 325-341. http://dx.doi.org/10.1023/A:1022005332110

Todosijevic, B. \& Enyedi, Z. (2008). Authoritarianism without Dominant Ideology: Political Manifestations of Authoritarian Attitudes in Hungary. Political Psychology, 29(5), 767-787. http://dx.doi.org/10.1111/j.1467-9221.2008.00663.x

Van IJzendoorn, M. H. (1989). Moral Judgment, Authoritarianism, and Ethnocentrism. The Journal of Social Psychology, 129(1), 37-45. http://dx.doi.org/10.1080/00224545.1989.9711697

Van IJzendoorn, M. H. (1997). Attachment, Emergent Morality, and Aggression: Toward a Developmental Socioemotional Model of Antisocial Behavior. International Journal of Behavioral Development, 21(4), 703-27. http://dx.doi.org/10.1080/016502597384631

White, F. A. (1996). Sources of Influence in Moral Thought: The New Moral Authority Scale. Journal of Moral Education, 25(4), 421-439. http://dx.doi.org/10.1080/0305724960250404 
White, F. A. (1997). Measuring the Content of Moral Judgment Development: The Revised Moral Authority Scale (MAS-R). Social Behavior and Personality, 25(4), 321-334. http://dx.doi.org/10.2224/sbp.1997.25.4.321

Table 1. Means and standard deviation of the moral authority subscales and authoritarianism

\begin{tabular}{lcccc}
\hline & \multicolumn{3}{c}{ Moral Authority } & Authoritarianism \\
\cline { 2 - 4 } Mean & Principle & External & Internal & \\
Std. Deviation & 84.7541 & 72.0164 & 37.8443 & 36.2373 \\
& 16.35268 & 16.93643 & 9.19038 & 5.13689 \\
\hline
\end{tabular}

Table 2. Descriptive analysis of the political attitude

\begin{tabular}{lll}
\hline & $\mathrm{N}$ & $\%$ \\
\hline very reformist & 39 & 30.5 \\
neither reformist nor conservative & 48 & 37.5 \\
somewhat conservative & 23 & 18 \\
very conservative & 9 & 7 \\
Missing & 9 & 7 \\
\hline
\end{tabular}

Table 3. Correlation of authoritarianism with self interest, external, and principle sources of moral authority

\begin{tabular}{lcccc}
\hline & 1 & 2 & 3 & 4 \\
\hline 1. Authoritarianism & - & & & \\
2. Self interest & .07 & - & & \\
3. External morality & $.18^{*}$ & $.49 * *$ & - & \\
4. Principle morality & .07 & $.60 * *$ & $.33 * *$ & - \\
\hline
\end{tabular}

Table 4. Results of ANOVA differences of moral authority sources and authoritarianism based on political attitude

\begin{tabular}{|c|c|c|c|c|c|}
\hline Variable & $\begin{array}{l}\text { Sam of } \\
\text { Squares }\end{array}$ & Df & MS & $\mathrm{F}$ & Sig. \\
\hline External Source & & & & .45 & .71 \\
\hline Between Groups & 393.81 & 3 & 131.27 & & \\
\hline Within Groups & 31603.26 & 109 & 289.93 & & \\
\hline Total & 31997.08 & 112 & & & \\
\hline Principle Source & & & & .28 & .83 \\
\hline Between Groups & 224.13 & 3 & 74.71 & & \\
\hline Within Groups & 28679.31 & 110 & 260.72 & & \\
\hline Total & 28903.44 & 113 & & & \\
\hline Self Interest Source & & & & .358 & .783 \\
\hline Between Groups & 90.03 & 3 & 30.34 & & \\
\hline Within Groups & 9319.22 & 110 & 84.72 & & \\
\hline Total & 9410.25 & 113 & & & \\
\hline Authoritarianism & & & & 2.06 & .10 \\
\hline Between Groups & 163.74 & 3 & 54.58 & & \\
\hline Within Groups & 2776.44 & 105 & 26.44 & & \\
\hline Total & 2940.18 & 108 & & & \\
\hline
\end{tabular}

